\title{
Satisfaction of Patients with Hospital Food Services
}

2IIIIIIIIIIIIIIIIIIIIIIIIIIIIIIIIIIIIIIIIIIIIIIIIIIIIIIIIIIIIIIIIIIIIIIIIIIIIIIIIIIIIIIII

1 Amer Ovčina

1 Sebija Izetbegović

1 Ernela Eminović

1 Clinical Centre of the University of Sarajevo, Bolnička 25, Sarajevo 71000, Bosnia and Herzegovina

\section{ABSTRACT}

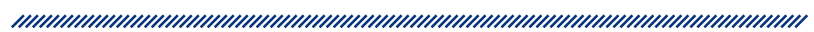

Introduction: satisfaction of patients has been frequently used as an indicator of quality in the healthcare sector. The analysis of patient satisfaction or experience in respect of hospital food is an important segment influencing the overall satisfaction with hospital services provided, and the study results should serve for the purpose of improving the service quality.

Aim: to analyse patient satisfaction with hospital food services, evaluate the level of satisfaction in respect of food distribution, and give recommendations for improvement of hospital food quality.

Materials and methods: the study included 300 patients hospitalized in the Clinical Centre of the University of Sarajevo (CCSU). The study used an anonymous, purposely designed questionnaire. The study was conducted in the period from 1 May to 31 August 2017.

Results: the study related to patient satisfaction with hospital food services showed that the respondents were satisfied with hospital food in the majority of cases. Few respondents were unsatisfied with food pro- vided from the central kitchen, specifically $5 \%$ of them; $25 \%$ of the respondents were unsatisfied with the nutritive value of the food, $6 \%$ of them were unsatisfied with the menu, and $10 \%$ of the respondents were unsatisfied with the dietary treatment.

Conclusion: nutrition of patients during their hospital treatment has significant influence on the overall recovery and it significantly affects the overall satisfaction regarding patients' treatment in hospital. Small number of the tested patients showed subjective perception in respect of nutritive value of the food and prescribed dietary regime.

Keywords: food, satisfaction, patients, hospital, quality

Article received: 13.02 .2018 .

Article accepted: 01.03.2018.

DOI: $10.24141 / 1 / 4 / 1 / 3$

Author for correspondence:

Amer Ovčina, PhD

Clinical Centre of Sarajevo University

Discipline for science and teaching

Organizational unit for quality i security of health services

Bolnička 25 Sarajevo 71000; Bosnia and Herzegovina 


\section{INTRODUCTION}

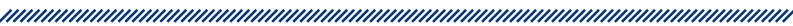

The evaluation of healthcare users' satisfaction is one of the basic elements for the promotion of the work quality in a healthcare institution and a precondition for quality healthcare. It is also a measure of patients' attitudes towards healthcare practitioners, the healthcare system and the healthcare provided. ${ }^{1}$

The degree of patient satisfaction with healthcare may serve as an indicator within the World Health Organization's "Health for All" (WHO HFA) program, and an indicator of healthcare quality. ${ }^{2}$

Integrating patients' opinions with other prescribed elements of healthcare quality, as defined in item 13 of the WHO HFA objective, would result in systemic monitoring of healthcare quality, which would subsequently result in the improvement of the quality of services provided within the healthcare system. In fact, the content of healthcare evaluation should not only be used to measure clinical and economic productivity, but also social acceptability. Social acceptability includes the community or public views on health, especially public views on different aspects of healthcare processes. Therefore, it is very important to measure patient satisfaction, especially because satisfaction of patients in the end influences one's health condition and the therapeutic outcome of the treatment. ${ }^{3,4}$

Patient satisfaction depends not only on characteristics of the healthcare provided, but also on the characteristics of the patient, his/her expectations and inclinations to criticize and commend. Sometimes the fulfilment of medical needs does not have to fulfil social and emotional needs, and besides, satisfaction of users may also include cultural background of the nation. ${ }^{5,6}$

Patient satisfaction in measuring healthcare quality is necessary for the inherent transformation of healthcare from the area of passive offer to the area of active demand for healthcare, where patient's needs are those that define part of the quality. Besides, patients in a democratic society must exercise their right to influence the decision-making process. Measuring patient satisfaction has become part of the societal participation in the overall healthcare system, and patients' opinion on the work of healthcare practitioners is an important element in establishing the quality thereof. ${ }^{2,7}$

Investigating user satisfaction aims at increasing the quality of services and medical treatments, humanity, better awareness and reduction of inequality. Satisfaction has changed over time, not only by getting a different definition, but the same person may come up with different judgments at different times. ${ }^{8}$

Patient satisfaction is frequently used as an indicator of quality in the healthcare sector. There have been a number of studies related to patient satisfaction. However, the answers obtained are subjective and their interpretation may be complex given that evaluation of satisfaction is a function of expectations, which probably varies among the patients. Constrains related to the investigation of patient satisfaction include the fact that sometimes they do not address "dissatisfaction" but simply evaluate the level of "satisfaction"; answers may be influenced by socially preferable positions or some other prejudice; and their results may frequently reflect a high level of satisfaction. ${ }^{6-8}$

In the framework of the establishment of a quality improvement system and safety of healthcare services, the Clinical Centre of the University of Sarajevo performs regular surveys among healthcare users regarding their satisfaction with the healthcare services provided. Summaries of the surveys are presented annually.

As for the analysis of user satisfaction with healthcare services, it also included their satisfaction with other services offered to hospitalized patients, which are not less significant, that are was also surveyed, such as their satisfaction with hospital food, hygiene, linen, etc. Besides the questionnaires, healthcare users may express their dissatisfaction in writing on the template form for remarks and compliments, which is regularly reviewed, analysed and evaluated. All justified suggestions, remarks and compliments of the patients actively participating in the healthcare process are used as guidelines for the promotion of quality and safety of healthcare services. ${ }^{9}$

\section{AIM OF THE STUDY}

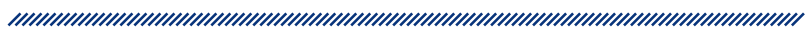

To explore the satisfaction of patients with hospital food services.

To evaluate the level of satisfaction based on the menu choice, amount, service and hygiene of food.

To provide patient recommendations for the improvement of hospital food quality. 


\section{MATERIALS AND METHODS}

"

The study was conducted in the period from 1 May to 31 August 2017. It included 300 patients hospitalized in the CCSU who filled out the questionnaire. Besides general questions, the questionnaire also contained questions related to satisfaction with hospital food services. Patients were conscious and oriented. They exclusively consumed food prepared in the central kitchen.

The questionnaire was anonymous, and the obtained results did not reveal identity of the respondents.

The patients were previously informed about the intention of the survey both in writing and orally. The participation in the survey was voluntary and the questionnaires were delivered to the patients by authorized nurses. Along with an oral explanation, the patients received a written explanation of the survey, the informed consent form, and the questionnaire which was to be filled out after signing the informed consent form. The informed consent form was immediately collected by authorized nurses and, following the survey, the questionnaires were placed in appropriate envelopes which were subsequently sealed and taken by the researcher personally. The respondents were provided anonymity in each segment of the survey, and data obtained in the survey could not be connected to personal data of the respondents.

Scoring, where applicable was done on a 1-5 scale (1poor, 2-weak, 3-good, 4-very good, and 5-excellent).

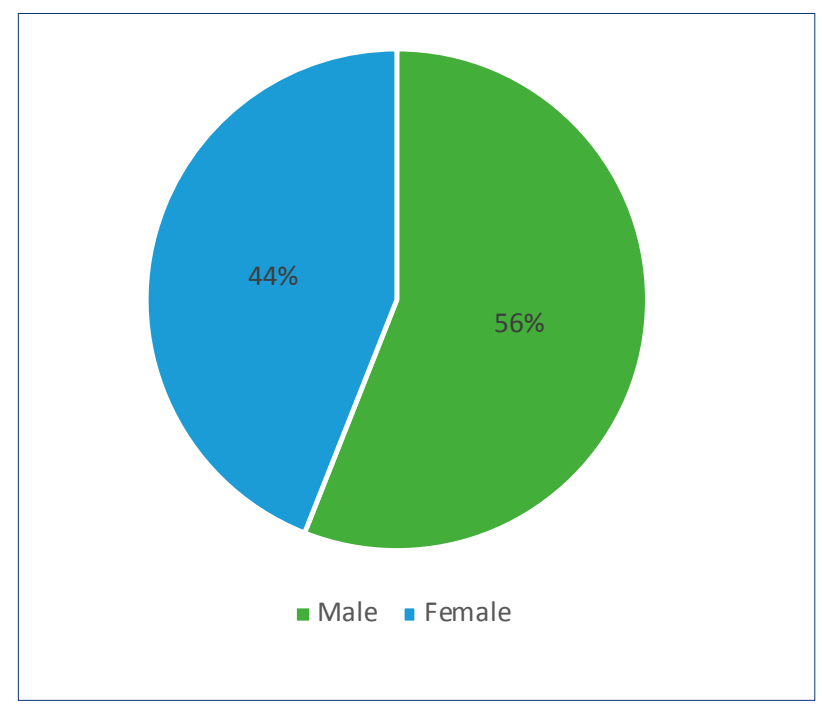

Figure 1. Gender structure of the respondents
The questionnaire consisted of five parts:

1. General part. Respondents provided answers regarding their gender, age, educational background and residence, as well as a subjective score of their health;

2. Satisfaction with food distribution. Patients answered 4 questions regarding their satisfaction with food distribution in the hospital;

3. Satisfaction with the visual appearance of food and taste. Respondents rated the visual appearance of food and taste by answering 4 different questions;

4. Satisfaction with the hospital diet and nutritive values of food. Patients answered 3 different questions that deal with the hospital diet and their opinion on nutritive values of food.

5. Patient recommendations for the improvement of nutrition. Patients could give their recommendations for the improvement of nutrition by selecting options and/or providing their own opinions regarding the matter.

\section{RESULTS}

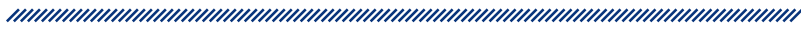

Figures 1-3 present the demographics of respondents included in the study. Figure 1 shows the gender structure of patients who filled out the questionnaire; out of

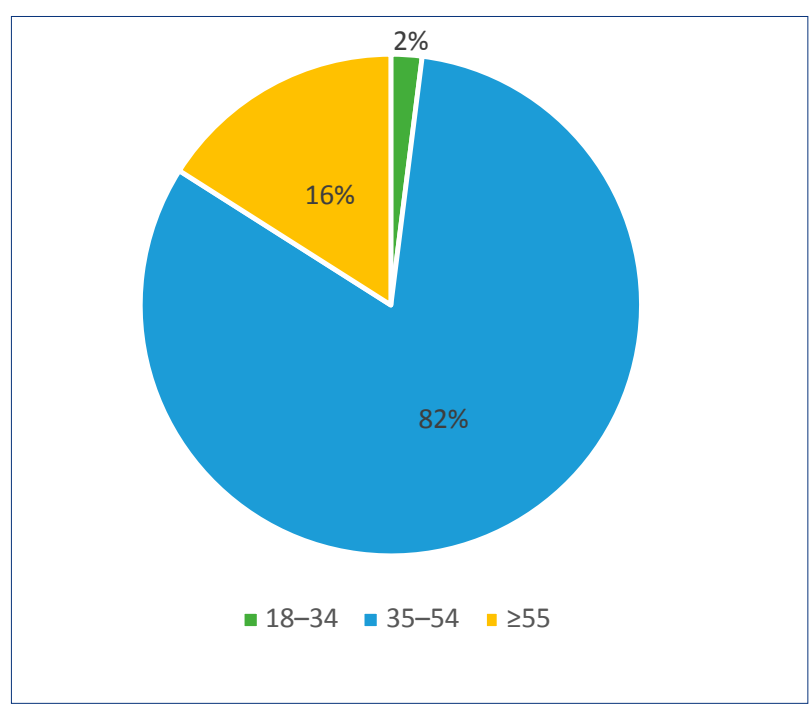

Figure 2. Age structure of the respondents 


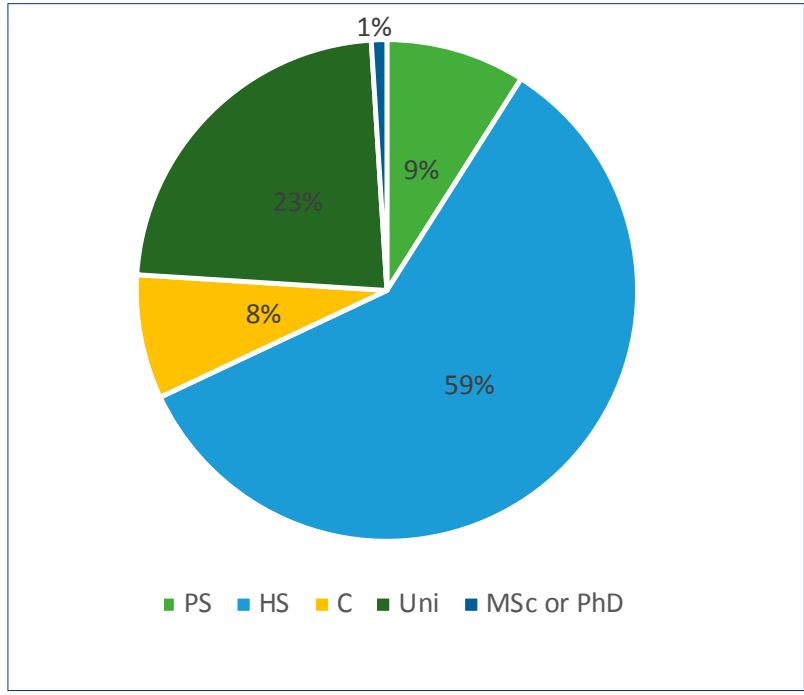

Figure 3. Educational background of the respondents

(PS - primary school, HS - high school, C - 2-year college, Uni - university degree, MSc or PhD - master of science or doctor)

300 persons, $56 \%$ of them were male and $44 \%$ female. Most of them were mid-aged; $82 \%$ were $35-54$ years old. As expected, very few of them were younger than 35 (2\%). Educational background of evaluated patients was diverse; most of them were high-school graduates (59\%), followed by respondents with a university degree $(23 \%)$. As expected, most of the patients come from the Sarajevo Canton (72\%), followed by the Zenica-Doboj, Central Bosnia, Una-Sana, Bosnian Podrinje and Herzegovina-Neretva Canton (Figure 4).

Patients were asked to give a subjective score on their health. Interestingly, more than $90 \%$ considered them-

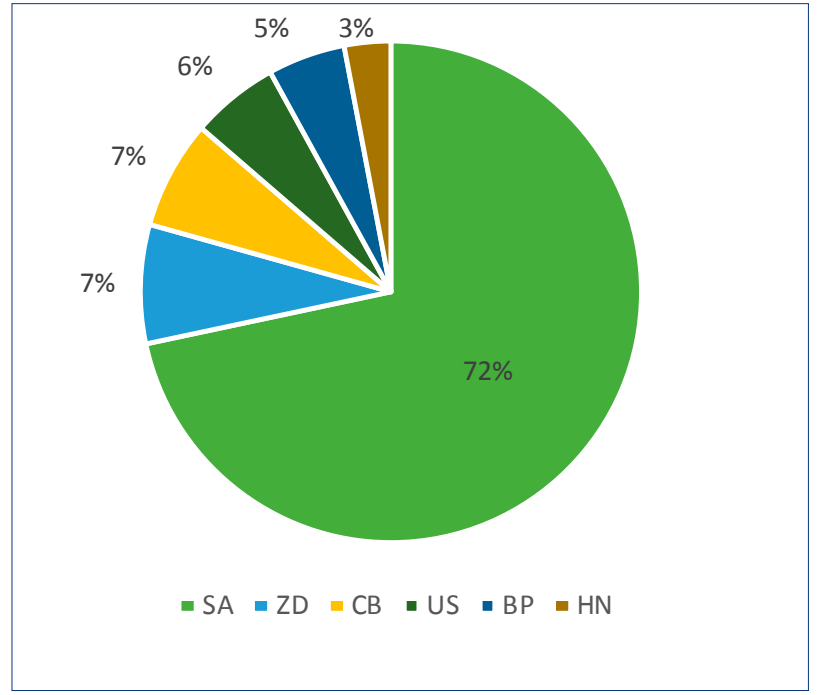

Figure 4. Distribution of the respondents based on their place/canton of residence SA - Sarajevo Canton, ZD - Zenica-Doboj Canton, CB - Central Bosnia Canton, US - Una-Sana Canton, BP - Bosnian Podrinje Canton, HN - Herzegovina-Neretva Canton)

selves to be in good (54\%), very good (29\%), or an excellent shape $(7 \%)$, while very few were unsatisfied with their health condition (Figure 5).

Patient satisfaction with food services was assessed with 11 questions classified in 3 groups: satisfaction with food distribution (Figure 6), satisfaction with the visual appearance of food and taste (Figure 7) and satisfaction with the hospital diet and nutritive values of food (Figure 8).

In general, the great majority of respondents were satisfied with food distribution. Very few patients were unsatisfied with the time of food serving (4.6\%), while some were not pleased with politeness of hospital servers (6\%).

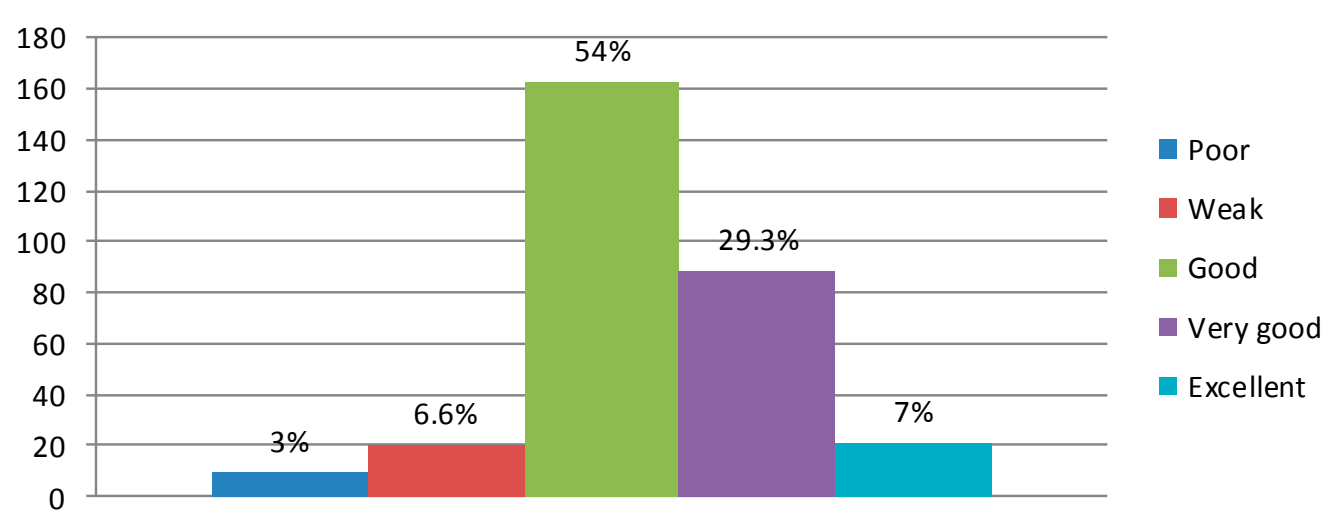




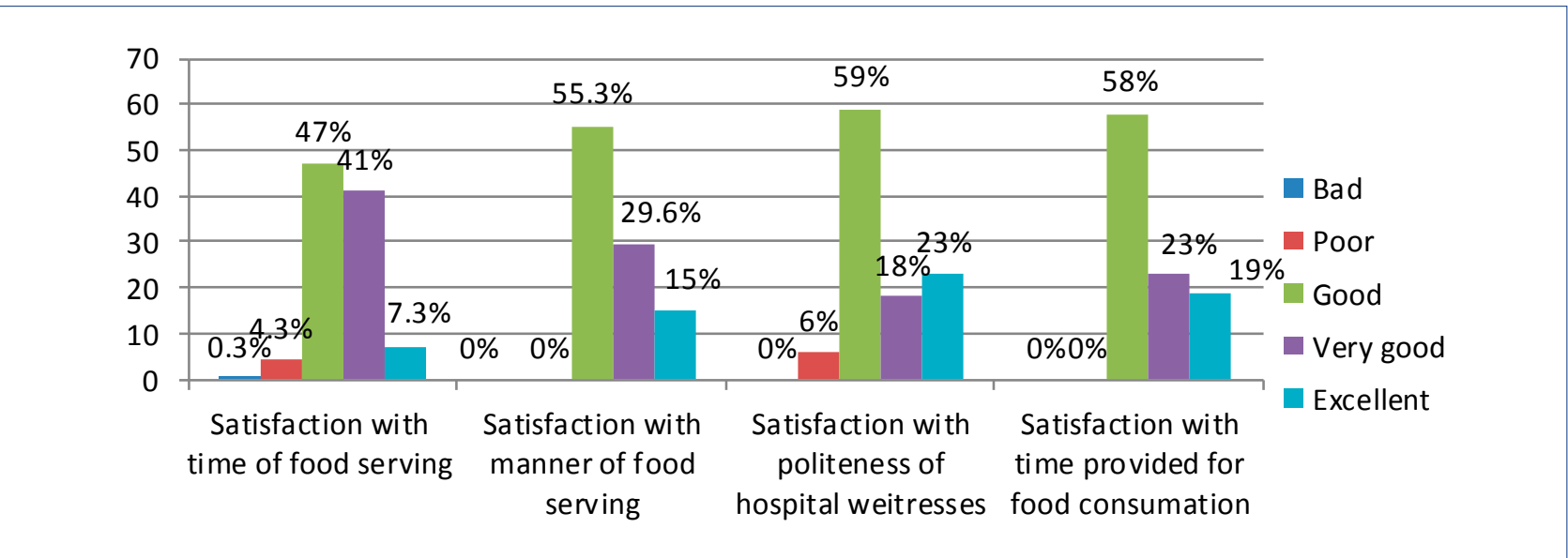

Figure 6. Satisfaction with food distribution

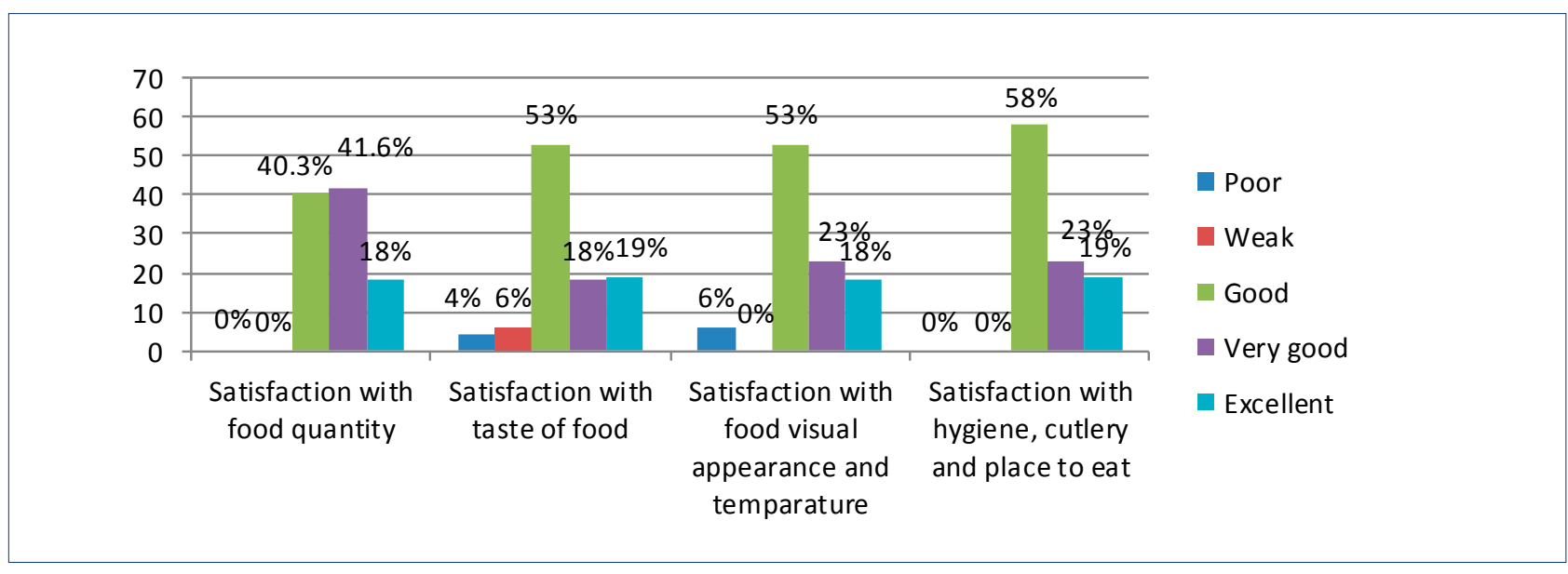

Figure 7. Satisfaction with the visual appearance of food and its taste

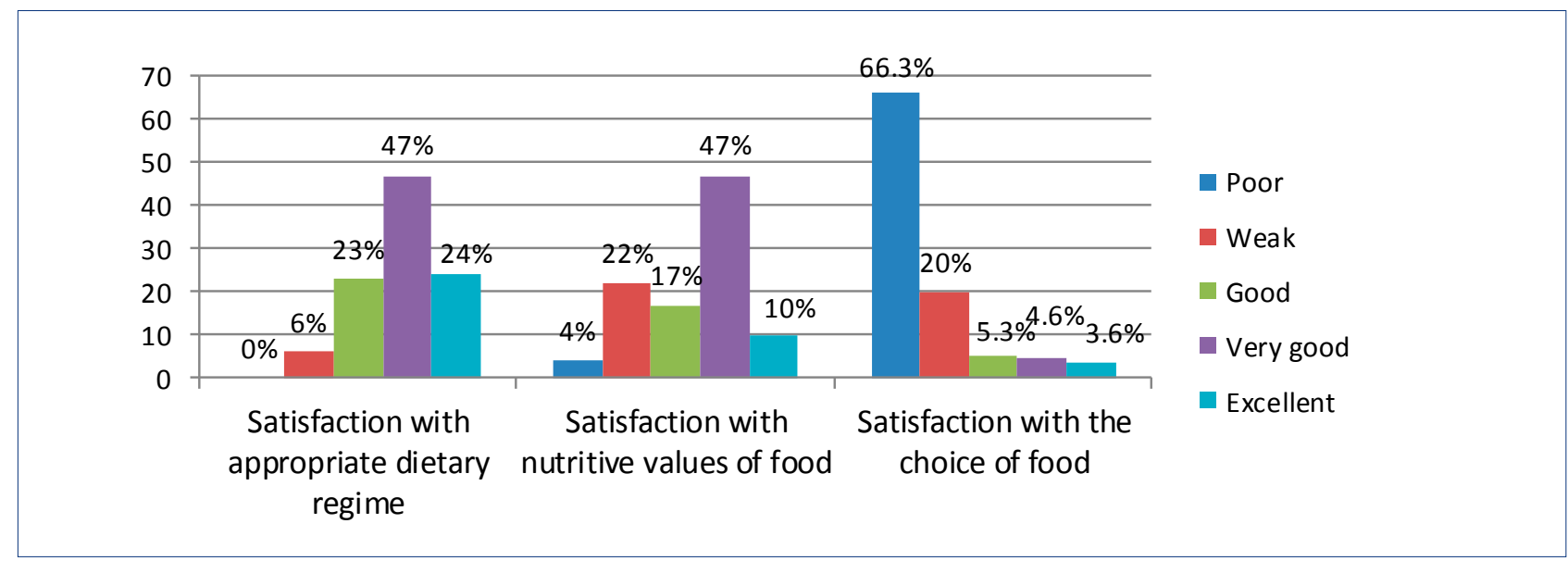

Figure 8. Satisfaction with the hospital diet and nutritive values of food

In all other cases, patients positively scored satisfaction with food distribution, including the manner of food serving and the time provided for food consummation.
The patients were not dissatisfied with the food's visual appearance and taste. Considering the general prejudice against 'hospital food', we found it interesting to 


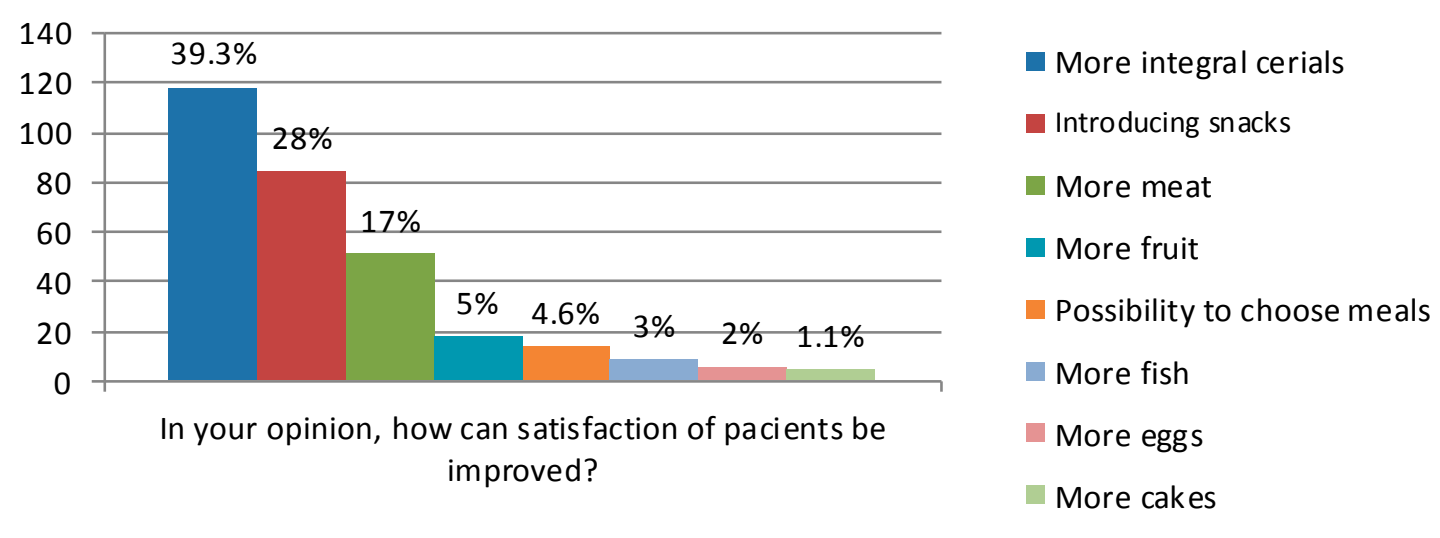

Figure 9. Patient recommendations for the improvement of nutrition

see that $90 \%$ of respondents were satisfied with food taste, while $96 \%$ considered its visual appearance and temperature to be either good, very good or excellent. There were no registered negative scores on the food quantity and hygienic conditions of the cutlery and places for eating.

However, the patients showed the greatest dissatisfaction with nutritive values of food. While $94 \%$ of them gave rated dietary regime positively, most were unsatisfied with the choice of food (86\%) and some expressed their doubts regarding nutritive values of food provided to them (26\%).

Figure 9 presents respondents' opinion regarding the improvement of food services. Most of them consider that integral cereals would improve the hospital food quality $(39 \%)$, some would like the introduction of snacks (28\%), while others asked for more meat (17\%), and fruit (5\%).

\section{DISCUSSION}

One of the basic human rights is the right to quality healthcare. The objective of each healthcare system is promotion and improvement of health quality, resulting in the improvement of the quality of life. ${ }^{5}$

The methodology related to the improvement of quality healthcare involves external and internal control, continuous quality improvement, evaluation of quality by measuring patient satisfaction and the use of clinical guidelines. In many European countries, the USA and Australia, monitoring patient satisfaction with healthcare and various levels thereof have become a regular practice. $^{3}$

The Federation of Bosnia and Herzegovina has adopted a number of laws defining the healthcare system, improvement of quality and safety of healthcare services, patient rights, and by-laws with clear instructions to establish standards and criteria for healthcare institutions and their respective services. Accordingly, methodological instructions and strategic goals have been enacted with the intention to provide maximum quality of healthcare services and enable active participation of users in the creation of quality and safe healthcare. ${ }^{1,2,8}$

Our study of patient satisfaction with hospital food services, as an important parameter influencing the overall quality of healthcare services, showed that in majority of cases the respondents were satisfied with hospital food. Fewer respondents expressed their dissatisfaction with food provided from the central kitchen, specifically $5 \%$ of them, whereas $25 \%$ of the respondents were unsatisfied with the nutritive value of food, $6 \%$ of them with the menu, and $10 \%$ of the respondents were unsatisfied with the dietary treatment.

The majority of the respondents, an average of $94 \%$, were satisfied with the visual appearance of food which was evaluated as good, very good and excellent. Satisfaction with food distribution was evaluated as good, especially the time of food serving and politeness of hospital servers. 
The respondents were unsatisfied with the possibility of meal selection, and $66.3 \%$ of them evaluated the choice of food as poor. It is necessary to point out that health professionals program the dietary regime of all patients, so the possibility of meal selection is limited.

Patients recommended introducing integral cereal into the menu which was supported by $39.3 \%$ of the respondents. Studies conducted in the region have shown similar results.

The study of patient satisfaction with the quality of healthcare services conducted in 2015 on 100 patients hospitalized in General Hospital in Zadar showed that the respondents rated their satisfaction with hospital food with 4 , on a provided scale of 1 to $5 .{ }^{10}$

A similar study was conducted in Daruvarske Toplice in 2015. It included 100 respondents, of which 6\% recommended more quality nutrition in order to improve the healthcare service quality. ${ }^{11}$

A study conducted in 2014 in General Hospital in Sremska Mitrovica included 173 patients. It showed that, on a provided scale of 1 to 5 , the respondents rated hospital food with an average score of 3.92. ${ }^{12}$

The studies conducted in the tertiary healthcare institutions in 2016 in Zrenjanin showed that among 20 questioned patients $90 \%$ was satisfied with hospital food, which they rated with an average score of $4 .{ }^{13}$

Studies related to user satisfaction with the functioning of secondary and tertiary healthcare institutions were conducted in 2014 at the Department of Internal Medicine, Surgical and gGynaecological Department, the Department of Physical Medicine and Rehabilitation and the Department of Specialist Services in 17 Belgrade hospitals. The results of the studies showed that patients were the least satisfied with the hospital food and accommodation. Satisfaction with the taste of food was recorded in $72 \%$ of patients, satisfaction with the variety of food in $73 \%$, and the food temperature in around $77 \%$ of patients. Satisfaction with the food quantity was recorded in $80 \%$ of patients, food serving in over $82 \%$ of patients, and the time of serving in around $86 \%$ of patients. An average score with regard to general satisfaction with food services was 4.08 , which was somewhat higher in relation to the previous year (4.02). The most satisfied with hospital food were patients hospitalized in the Special Hospital for Endemic Nephropathy and the Special Hospital for Orthopaedic Prosthetics. ${ }^{14}$

A study of satisfaction with hospital food was conducted in 2011 among 644 patients hospitalized in general and special hospitals of the Raška region, the Republic of Serbia.

With regard to user satisfaction with food services, patients hospitalized in general and special hospitals of the Raška region rated their satisfaction with 4.05. Taking into account various aspects of satisfaction with this type of service, patients were the least satisfied with the taste and the variety of food and the most satisfied with the time and manner of food serving. ${ }^{15}$

\section{CONCLUSION}

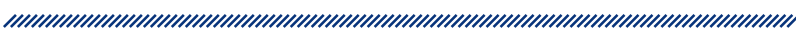

Nutrition of patients during their hospital treatment has an important influence on the overall recovery and it significantly affects the overall patient satisfaction with hospital treatment. The majority of respondents expressed their satisfaction with the distribution of hospital food, as well as its appearance and taste $(>90 \%)$. Few surveyed patients expressed their negative perception in respect of nutritive value of food and the prescribed dietary regime, while the major source of dissatisfaction was the choice of food.

Studies related to satisfaction with hospital food services allow for active participation of patients in the treatment and care, because they can give their suggestions, proposals and comments on the provided meals. This also enables patients to become educated on hygiene and dietary regime as well as to change their irregular nutrition habits.

We recommend studying hospital experiences of patients more frequently. We believe they should include information about patients' experience of services provided in the hospital, which would be useful for the improvement of quality and safety of all services provided in hospitals.

\section{CONFLICT OF INTEREST}

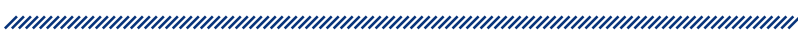

None declared. 


\section{REFERENCES}

8. Pijalović V. Značaj i mjerenje kvaliteta u zdravstvu. U: 6 Naučno-stručni skup sa međunarodnim učešćem "Kvalitet 2009". Neum; 2009. str. 851-6.

9. Klinički centar Univerziteta u Sarajevu. Izvještaj o indikatorima kvaliteta i sigurnosti zdravstvenih usluga u Kliničkom centru Univerziteta u Sarajevu. 2016.

1. Agencija za kvalitet i akreditaciju u zdravstvu FBiH. Akreditacijski standardi za bolnice. Sarajevo: AKAZ; 2010. 314 str.

2. Agencija za kvalitet i akreditaciju u zdravstvu FBiH. Indikatori kvaliteta i sigurnosti zdravstvenih usluga. Sarajevo: AKAZ; 2010.

3. WHO Regional office for Europe. Health for all: List of Statistical Indicators. Copenhagen; 1993.

4. Eldar R. Academic medicine and quality of medical care. Croatian medical journal. lipanj 2004.;45(3):256-8.

5. Huseinspahić N. Kvalitet kao pretpostavka za zadovoljstvo pacijenata. South Eastern Europe Health Sciences Journal. 2011.;1(1):67-73.

6. Čerfalvi V, Benceković Ž. Patient complaints - tool for improving service quality in hospitals. Poslovna izvrsnost. lipanj 2017.;11(1):63-9.

7. Krstić Vukelja E, Klaić B, Vukelja M, Duplančić I. Ispitivanje zadovoljstva pacijenata-model za rukovođenje, praćenje, evaluaciju i unapređenje kvalitete usluge zdravstvene zaštite. U: 10 Hrvatska konferencija o kvaliteti. 2010. str. 11.

10. Gusar I. Zadovoljstvo bolesnika kvalitetom pruženih usluga u Općoj bolnici Zadar. Sveučilište u Splitu; 2015.

11. Bis Z. Zadovoljstvo korisnika zdravstvenim uslugama u Daruvarskim toplicama, specijaliziranoj bolnici za medicinsku rehabilitaciju. Visoka tehnička škola u Bjelovaru; 2016.

12. Opšta bolnica Sremska Mitrovica. Završni izveštaj o proceni zadovoljstva korisnika zdravstvenom zaštitom i zaposlenih Opšte bolnice Sremska Mitrovica za 2014. godinu. Sremska Mitrovica; 2014.

13. Opšta bolnica Zrenjanin. Istraživanje zadovoljstva korisnika usluga u specijalističkim službama interne medicine u Opštoj bolnici Zrenjanin u 2016. godini. Zrenjanin; 2016.

14. Gradski zavod za javno zdravlje. Izveštaj o zadovoljstvu korisnika u bolnicama u Beogradu u 2015. godini. Beograd; 2015.

15. Zavod za javno zdravlje. Istraživanje zadovoljstva korisnika zdravstvenom zaštitom na Raškom okrugu u 2011. godini. Kraljevo; 2011. 


\section{ZADOVOLJSTVO PACIJENATA USLUGAMA BOLNIČKE ISHRANE}

\section{SAŽETAK}

Uvod: Zadovoljstvo pacijenata sve se više upotrebljava kao indikator kvalitete u zdravstvenom sektoru. Ispitivanje zadovoljstva ili iskustava pacijenata s prehranom u bolnici predstavlja važan segment koji utječe na opće zadovoljstvo pruženim zdravstvenim uslugama u bolni$\mathrm{ci}$, a rezultati ispitivanja moraju služiti u svrhu poboljšanja kvaliteta usluga.

Cilj rada: Ispitati zadovoljstvo pacijenata uslugama bolničke prehrane, ocijeniti stupanj zadovoljstva distribucijom hrane te prikazati preporuke za unaprjeđenje kvalitete bolničke prehrane.

Metode istraživanja: Istraživanje je provedeno među 300 hospitaliziranih pacijenata u Kliničkom centru Univerziteta u Sarajevu. Za istraživanje je primijenjen namjenski konstruiran anonimni anketni upitnik. Istraživanje je provedeno u periodu od 1 . svibnja do 31 . kolovoza 2017.

Rezultati istraživanja: Naše je istraživanje pokazalo da su ispitanici u najvećem broju slučajeva zadovoljni bolničkom prehranom. Manji je broj ispitanika nezadovoljan hranom iz centralne kuhinje, i to $5 \%, 25 \%$ ispitanika nije zadovoljno nutritivnom vrijednošću obroka, $6 \%$ jelovnikom, a $10 \%$ provođenjem dijetetskog tretmana.

Zaključak: Prehrana pacijenata za vrijeme bolničkog tretmana ima važan utjecaj na cjelokupni oporavak od bolesti i znatno utječe na opće zadovoljstvo pacijenta tretmanom u bolnici. Manji broj ispitanika subjektivno percipira nezadovoljstvo nutritivnom vrijednošću obroka i provođenjem propisane dijete. 